ISSN : $2302-1590$

E-ISSN: $2460-190 X$

Economica: Journal Of Economic And Economic Education

Volume 10, Issue. 1, October 2021, pp 85-91

\title{
TOURISM RECOVERY STRATEGY AFTER COVID-19 PANDEMIC
}

\author{
Erna Susanti ${ }^{1)}$,Deni Amelia ${ }^{2)}$ \\ ${ }^{1)}$ Computer Science Faculty, Universitas Putra Indonesia YPTK Padang, Indonesia \\ Email: ernasusan77@gmail.com \\ ${ }^{2)}$ Computer Science Faculty, Universitas Putra Indonesia YPTK Padang, Indonesia \\ Email: deniamelia10@gmail.com \\ Submitted: 2021.03.18 Reviewed: 2021.06.28 Accepted:2021.10.30 \\ https://doi.org/10.22202/economica.2020.v9.i1.3935
}

\begin{abstract}
The Covid-19 pandemic has resulted in turbulence in all sectors. The rapid spread of the virus has caused the government to quickly adopt policies. The tourism sector is a sector that has been severely shaken due to this pandemic. The tourism sector and its supporting industries have almost collapsed and their activities have stopped. This study is aimed to determine the recovery strategy for the tourism sector and the creative economy of Padang City after the Covid-19 pandemic. This research is a descriptive qualitative study with data collection techniques by using the triangulation method: the collection of research data that is using observation techniques, in-depth interviews, and document analysis. The result of this research is that the recovery strategy of the tourism sector and the creative economy in Padang City is carried out by rehabilitating and maintaining infrastructure, revitalizing both destinations and attractions, and creative economy businesses as well as promotion to stimulate the tourism sector.
\end{abstract}

Jel Clasification:

C4; M2; L83; M30; M30

Keywords: strategy, recovery, pandemic, creative economy, tourism, Covid-19 


\section{INTRODUCTION}

The Covid-19 pandemic has begun at the end of 2019 in Wuhan City, China. Many residents of Wuhan City have contracted this virus. The policy of the Wuhan City government to carry out a total lockdown to prevent this virus from spreading out has been applied to other cities in China as well. Coronavirus (Covid-19) can quickly be transmitted through droplets and physical contact. This caused this virus to rapidly develop in various countries and made it a pandemic. Covid-19 entered and developed in Indonesia in early March 2020. The economy in Indonesia was also affected by this virus. According to (Aditia et al., 2020), the impact of the Covid-19 pandemic caused low investor sentiment towards the market which in turn led the market towards a negative trend. The social and economic aspects of the community were also affected as (Azimah, Rizki Nor Khasanah \& Pratama, 2020)stated that the impact of this pandemic on the economy has decreased, especially in market traders who experienced a decline in turnover and income by $50 \%$.

The determination of the PSBB (Large-Scale Social Restrictions) made the government issue several policies, including the policy of working from home and studying at home. This, of course, creates a lot of uneasiness because it is very suddenly unexpected without preparation, teaching and learning activities are moved at home by e-learning using various technological tools, such as smartphones, computers, and notebooks (Zaharah \& Kirilova, 2020). The learning dynamics in Indonesia are currently being disrupted externally by the Covid-19 crisis, some of the impacts include; schools are shifted to home through an online learning process; there is a transformation of technology-based learning media through the use of WhatsApp Group, Zoom, Google Classroom, WebEx, Youtube, and TV channels; adjustment of learning methods; adjusting learning evaluation to determine standards for class promotion and graduation; and demands for collaboration between parents at home as a substitute for teachers in controlling children's learning (Mansyur, 2020).

One of the sectors that have been most impacted is the tourism sector. Travel restrictions and lockdown policies made many trips being canceled. According to(Soehardi, Permatasari, et al., 2020), there is an influence of the Covid-19 pandemic on foreign and domestic tourist visits in Indonesia. Many foreign tourists have postponed their visit to Indonesia due to the prolonged duration of the Covid-19 pandemic from March to June 2020. Many tourists decided to cancel or postpone their trip, tourists decided to immediately cancel their trip and began discussing the issue of travel insurance (Uğur \& Akbıyık, 2020). According to(Neuburger \& Egger, 2020), the perception of travel risks and media coverage of the development of Covid-19 made tourists cancel their trips.

The Covid-19 pandemic has inflicted chaos in all sectors in Padang City, such as the education, health, economy, and tourism sectors. Planning and activities that have been made cannot be realized. Work programs and events, both national and international, must be rescheduled. This requires the city government to work hard to formulate policies to deal with this pandemic. The government's attention is mostly devoted to handling exposed patients, creating preventive actions so that this virus does not take more victims, and looking at the economic growth that is slowing down due to the impact of this pandemic.

The tourism sector in Padang city is severely shaken and has suffered huge losses. This is because of the travel ban and lockdown policies in various countries, including Indonesia that implemented the PSBB (Large-Scale Social Restrictions) which has caused a significant reduction in the level of tourist visits from within and outside the country and impacted tourism supporting industries. For this reason, this study is aimed to see the strategy of the Padang City Government in dealing with the Covid-19 pandemic. Numerousearlierliteratures have stated a recovery strategy against p covid-19 pandemic, open communication is a key success to combat pandemic and government-sponsored loans a crucial to the survival tourism industry (Yeh, 
2021). According to (Hosseini et al., 2021), standardization of the centers, estimating demand number and increasing capacity, and identifying other natural tourist attractions of the region have the highest and lowest priority to be implemented in eco-tourism centers. The pandemic has opened an opportunity to reflect on the pre-existing issues on tourism and reset the current approach for more responsible and sustainable tourism industry in the future(Goh, 2021). Based on these differences, it can be seen that the recovery strategy had different models strategy.

\section{METHODS}

This research uses a descriptive research method. The descriptive research model is used to describe various aspects of the phenomenon. This model was previously developed by (Kusuma, 2021) and this model was modified by adding a different content analysis with previous research which only used document studies. The focus of the research provides an overview of the creative economy recovery strategy and the tourism sector in the city of Padang after the Covid-19 pandemic. Sources of data used are primary data and secondary data. Data collection techniques using observation, interviews, and document analysis. Measurement of the validity of the data is done by triangulation of sources. Data analysis using qualitative descriptive analysis (Milles, M.B., Huberman, M, A., 2014).

\section{RESULT AND DISCUSSION}

This research was carried out in 5 stages, namely analyze, design, develop, a. The impact of the Covid 19 pandemic on the creative economy and tourism sector. First, the rate of tourist visits and hotel occupancy has dropped significantly. The spread of the Covid-19 virus is quickly and almost infected the entire world community, which caused almost all business sectors to seemingly have stopped. It can be seen from the number of companies and businesses that reduce and temporarily stop their operations; so the creative economic sector and tourism are. The closure of airports and tourist attractions has brought the creative economy and tourism sector to a halt. Many of the travel agencies, hotels, restaurants, and tourism support industries have stopped operating. Second, the trend of reducing ticketing requests and tourist travel activities has reached $90 \%$. The prohibition of traveling in almost every country has an impact on ticketing requests and significantly reduces the number of tourist trips. This condition inflicts a significant reduction in hotel occupancy rates. Hospitality and restaurant activities seem to not have any significant activities. This made the hotel management adopt a policy to reduce employees by laying them off. This is presented in table 1 below.

Table 1. Estimated Number of Job Terminations in the Tourism Sector in Padang City, March - May 2020 Period

\begin{tabular}{llcc}
\hline No & Types of Work & $\begin{array}{c}\text { Number of Job } \\
\text { Termination }\end{array}$ & Percentage (\%) \\
\hline 1 & Hotel & 1,268 & 35 \\
2 & Restaurant & 1,428 & 40 \\
3 & Entertainment & 876 & 25 \\
\hline
\end{tabular}

Resource: Padang City Government 
From table 1 above, the total number of job termination was 3,571 people, where the largest layoffs occurred in the restaurant business at $40 \%$, followed by the hotel business at $35 \%$ and the entertainment business at $25 \%$. This, of course, will increase the number of unemployment in Padang city. Third, the reduced average income of business actors and the tourism industry. The decrease in the number of tourist visits will have an impact on the supporting industries of tourism activities, including the creative industry which produces a lot of artistic and creative products, traders around tourist destinations, and actors of artistic and cultural attractions. This is presented in table 2 below.

\begin{tabular}{|c|c|c|c|}
\hline No & Types of Tourism Support Industry & Unit (person) & $\begin{array}{l}\text { Amount } \\
\text { (million) }\end{array}$ \\
\hline 1. & $\begin{array}{l}\text { Culinary (Air Manis Beach \& Padang } \\
\text { Beach) }\end{array}$ & 102 & 1,710 \\
\hline 2. & Rides (ATV, Becak) & 185 & $1,387.5$ \\
\hline 3. & Creative economy & 428 & 1,382 \\
\hline
\end{tabular}

Resource : Padang City Government

The decrease of income toward tourist attractions will affect the performance of tourism sector employees(Soehardi, Purnamaasih, et al., 2020). The rapid spread of the virus requires the government to adopt various policies for handling exposed patients and taking precautions so that it does not develop more widely. One of them is the establishment of a Task Force (Satgas) at the regional and national levels. Recovery from the impact of Covid-19 is carried out in several stages, this is because the recovery process requires a long process, and this pandemic is still not overdue to the rapid spread of the virus itself and there are still people who are exposed. Emergency Response Stages: budget relocation and rescheduling of activities; closing/limiting the operation of tourist attractions and tourism supporting industries; data collection on parties affected by the pandemic, in the economic sector such as the provision of tax breaks, banking relaxation, health protocol regulations.

The recovery phase after the pandemic is declared over, rehabilitation, maintenance of tourism amenities infrastructure, revitalization, strengthening of attractions, destinations, tourism industry businesses, promotions, event implementation, discounting, and vouchers for stimulus on tourist/travel and tour guides. The provision of a discount giving and other facilitations in hotel services is one of the strategies to increase occupancy rates, as it is done with several hotels in Bali by making policies like temporarily laying off employees without a clear limit when they are rehired, limiting the use of hotel facilities to reduce operating costs, hotel spending efficiency, online sales of non-room products to acquaintances and former hotel room users, conducting a "pay now stay later" model, refusing booking refunds by replacing visit reschedules (Anak Agung Gede Raka \& Yasa, 2020). According to (Sugihamretha, 2020), there are several recommendations for policy responses for tourism: protecting workers' livelihoods, providing financial support to companies in the tourism industry, injection of liquidity and cash to small and large tourism industry players, designing an android-based tourism information system application in which there is a collection of tourism industry data that provides data on tourism human resoures, types of services, attractions, and tourist facilities spreading across Indonesia, applying discounts for aircraft landing and parking fees as well as discounted rental rates for shops and cargo agents at airports in Indonesia, offering training scholarships at the Polytechnic of Tourism and extending deadlines for payment of taxes and other obligations. It is necessary to design funding sources for rapid disaster management in the tourism sector such as short-term funding schemes, credit schemes, 
working capital for UMKM, the informal sector, and applying corporate income tax deductions, establishing disaster mitigation institutions in the tourism sector at the central level to regencies/cities, and compile a standard guidebook regarding planning, implementation, and control of the impact of an outbreak/disaster in the tourism sector.

The government, both the central and local governments, play a major role in overcoming this pandemic problem such as economic recovery and the tourism industry. The tourism recovery strategy in the New Normal includes applying adequate hygiene and safety standards for tourists, providing an alternative to new tourism patterns; staycation, niche tourism, solo travel tours, wellness tours, virtual tourism (Bagus et al., 2020). Normal stage, when the pandemic has ended and all activities return to normal and stable, the strategy taken is to increase synergy between sectors and all elements support (stakeholders) who are responsible for this industry to continue the sustainable tourism development program.

\section{CONCLUSION}

As stated by the results and discussions carried out in this study regarding the postcovid-19 recovery strategy in the city of Padang consisting of the emergency response stage strategy, the recovery stage strategy after Covid-19 ended, the normal and stable strategy. The results also found strategies to face the new normal era that can be applied in the post-pandemic tourism sector. This finding is different from the previous findings put forward by (Kusuma, 2021) who found that the recovery of the tourism sector in DIY could not be done quickly. Several stages must be passed. Tourism in DIY needs to be shifted from relying on mass tourism to class tourism. Visitors to tourist destinations are limited according to their optimal capacity towards sustainable tourism. The development of SMART Tourism requires tourism innovation in DIY based on information technology. Collaboration between tourism industry players, government, universities, and the community is needed so that SMART Tourism can be built and developed. Through the development of innovative tourism and the fulfillment of health protocols and standardization of international standard tourism services, tourism in DIY is expected to recover in 2022. 2021 is the year of optimal implementation of SMART Tourism. 2022 is expected to be the year of the recovery of the tourism sector in DIY which is more qualified and reliable. 


\section{REFERENCE}

Aditia, D., Nasution, D., Sains, F. S., Pembangunan, U., Budi, P., \& Utara, U. S. (2020). Aditia, 2020. Jurnal Benefita, 5(2), 212-224.

Anak Agung Gede Raka, N. A., \& Yasa, P. N. S. (2020). Jurnal Kajian Bali. Jurnal Kajian Bali, 10(23), 95-118.

Azimah, Rizki Nor Khasanah, I. N., \& Pratama, et all. (2020). Analisis Dampak Covid-19 Terhadap Sosial Ekonomi Pedagang Di Pasar Klaten Dan Wonogiri. EMPATI: Jurnal Ilmu Kesejahteraan Sosial, 9(1), 59-68. https://doi.org/10.15408/empati.v9i1.16485

Bagus, I., Paramita, G., Gede, I., Purnama, G., \& Putra, A. (2020). New Normal Bagi Pariwisata Bali Di Masa Pandemi Covid 19. Pariwisata Budaya: Jurnal Ilmiah Agama DanBudayahttps://garuda.kemdikbud.go.id/journal/view/16153?issue =Vol\%205,\%20N o\%202\%20(2020).

Goh, H. C. (2021). Strategies for post-Covid-19 prospects of Sabah's tourist market Reactions to shocks caused by pandemic or reflection for sustainable tourism? Research in Globalization, 3, 100056. https://doi.org/10.1016/j.resglo.2021.100056

Hosseini, S. M., Paydar, M. M., \& Hajiaghaei-Keshteli, M. (2021). Recovery solutions for ecotourism centers during the Covid-19 pandemic: Utilizing Fuzzy DEMATEL and Fuzzy VIKOR methods. Expert Systems with Applications, 185(June), 115594. https://doi.org/10.1016/j.eswa.2021.115594

Kusuma, P. A. (2021). Strategi Pemulihan Dampak Wabah Covid Pada Sektor Pariwisata Di Daerah Istimewa Yogyakarta. JOURNAL OF TOURISM AND ECONOMIC, 4(1), 47-59. https://doi.org/https://doi.org/10.36594/jtec.v4i1.110

Mansyur, A. R. (2020). Dampak COVID-19 Terhadap Dinamika Pembelajaran Di Indonesia. Education and Learning Journal, 1(2), 113. https://doi.org/10.33096/eljour.v1i2.55

Milles, M.B., Huberman,M,A. (2014). Qualitative Data Analysis A Methods (Sourcebook). In Sage Publishing.

Neuburger, L., \& Egger, R. (2020). Travel risk perception and travel behaviour during the COVID-19 pandemic 2020: a case study of the DACH region. Current Issues in Tourism, O(0), 1-14. https://doi.org/10.1080/13683500.2020.1803807

Soehardi, S., Permatasari, D. A., \& Sihite, J. (2020). Pengaruh Pandemik Covid-19 Terhadap Pendapatan Tempat Wisata dan Kinerja Karyawan Pariwisata di Jakarta. Jurnal Kajian Ilmiah, 1(1), 1-14. https://doi.org/10.31599/jki.v1i1.216

Soehardi, S., Purnamaasih, L., \& Rapitasari, D. (2020). Dampak Pandemik Covid-19 Terhadap Kunjungan Turis Asing dan Domestik serta Tingkat Hunian Kamar Hotel Bintang di Indonesia. Jurnal Kajian Ilmiah, 20(3), 291-308. https://doi.org/10.31599/jki.v20i3.287

Sugihamretha, I. D. G. (2020). Respon Kebijakan: Mitigasi Dampak Wabah Covid-19 Pada Sektor Pariwisata. Jurnal Perencanaan Pembangunan: The Indonesian Journal of Development Planning, 4(2), 191-206. https://doi.org/10.36574/jpp.v4i2.113

Uğur, N. G., \& Akbı1yk, A. (2020). Impacts of COVID-19 on global tourism industry: A crossregional comparison. Tourism Management Perspectives, 36(September), 100744. https://doi.org/10.1016/j.tmp.2020.100744

Yeh, S. S. (2021). Tourism recovery strategy against COVID-19 pandemic. Tourism Recreation Research, 46(2), 188-194. https://doi.org/10.1080/02508281.2020.1805933 
Zaharah, Z., \& Kirilova, G. I. (2020). Impact of Corona Virus Outbreak Towards Teaching and Learning Activities in Indonesia. SALAM: Jurnal Sosial Dan Budaya Syar-I, 7(3). https://doi.org/10.15408/sjsbs.v7i3.15104 